\title{
HISTOLOGICAL INVESTIGATION ON ANCYROCEPHALUS PARADOXUS (DACTYLOGYRIDEA: ANCYROCEPHALIDAE) INFECTION CAUSING MORTALITIES IN AN INTENSIVELY CULTURED PIKEPERCH [SANDER LUCIOPERCA (L.)] STOCK
}

\author{
Kálmán MOLNÁR ${ }^{1}$, Gábor SZILÁGYI ${ }^{2}$, Gábor MOSONYI ${ }^{2}$, Ádám VARGA ${ }^{1}$ \\ and Csaba SZÉKELY ${ }^{1 *}$ \\ ${ }^{1}$ Institute for Veterinary Medical Research, Centre for Agricultural Research, \\ Hungarian Academy of Sciences, P.O. Box 18, H-1581 Budapest, Hungary; \\ ${ }^{2}$ Elöre Fishery Cooperative Győr, Kisbajcs, Hungary
}

(Received 25 November 2015; accepted 4 May 2016)

\begin{abstract}
In a cultured pikeperch (Sander lucioperca) stock the monopisthocotylean monogenean gill parasite Ancyrocephalus paradoxus caused heavy infection and mortalities. The gills of the affected fish specimens were infected by 50 to 800 monogenean parasites. Severe pathological changes were found in areas where the worms attached to the gills. At the attachment sites the haptoral discs of the worms formed a deep depression in the epithelium of the filaments, and the anchors pierced into and fixed themselves to the connective tissue of the cartilaginous gill rays. At these attachment sites red blood cells released from injured capillaries were found among the damaged epithelial cells. Around the hooks, anchors and body sections coming into contact with the gill filaments a proliferative tissue developed in which only a remnant of the damaged lamellae was found. Due to the damage caused by the worms the tips of the heavily infected gill filaments fused, formed clubs and were composed of epitheloid-type regeneration tissue lacking respiratory lamellae. In the basal parts of the filaments, where most of the worms attached to the gill, only denuded filaments deprived of lamellae were observed among the cross-sectioned worms in histological sections.
\end{abstract} culture

Key words: Pikeperch, monogenean infection, histology, gills, intensive

The pikeperch [Sander lucioperca (L.)] is a valuable, high-quality freshwater predator fish of the Hungarian fish fauna, which feeds exclusively on moving live food. Efforts have been made to culture this fish in large-volume intensive systems and feed it with pelleted food (Peterka et al., 2003; Zakęś et al., 2006, 2013). Up to this time no reports have been published on diseases of cultured pikeperch populations. However, in 2015 a heavy monogenean infection caused by Ancyrocephalus paradoxus Creplin, 1839 was recorded in an inten-

*Corresponding author; E-mail: szekely.csaba@agrar.mta.hu; Phone: 0036 (1) 467-4065 
sively cultured pikeperch stock. Ancyrocephalus paradoxus, a specific parasite of the pikeperch, is one of the longest known dactylogyrid monogeneans. In Hungary, the occurrence of this species on the gills of pikeperch is well known in Lake Balaton and in some rivers (Molnár, 1962, 1968b), and its prevalence on the gills of pikeperch in different parts of Europe is also well documented (Gussev, 1985). Less frequently this parasite infects the Volga pikeperch (Sander volgensis Gmelin) as well (Gussev, 1985; Molnár and Székely, 1995). Ergens (1966) described the rare occurrence of a morphologically similar species, Ancyrocephalus percae on the common perch [Perca fluviatilis (L.)]. An outbreak caused by that species was reported to negatively impact the stock of the Eurasian perch in Lake Constance (Behrmann-Godel et al., 2014). Little is known about the pathological effect of $A$. paradoxus, although Starovoytkov (1989) observed that this species prefers to develop in specific segments of the hemibranchia, namely at its curve and at the two margins where it causes local damage to the gill filaments.

Monogeneans are well-known pathogens in cultured cyprinid fishes. The first record of a heavy monogenean infection dates back to 1929, when dactylogyrosis of common carp fry caused by Dactylogyrus vastator Nybelin was first described in densely populated nursing ponds (Wunder, 1929). A similar disease developed when Dactylogyrus extensus Mueller et van Cleave was introduced to Europe (Bauer and Nikolskaya, 1954; Prost, 1963). Wilde (1937) reported that another cyprinid fish, the tench [Tinca tinca (L.)] cultured in German fish ponds was similarly affected by its specific parasite, Dactylogyrus macracanthus Wegener. Bauer et al. (1969) reported that other cyprinid fishes such as the grasscarp, the silver carp and the bighead may also be severely affected by their specific Dactylogyrus spp. Of these monogenean species, D. lamellatus Achmerov infecting grasscarp fingerlings was studied in detail by Molnár (1971, 1972).

In non-cyprinid fishes, monogenean infection of the sheatfish [Silurus glanis (L.)] was studied (Molnár, 1968a, 1980). The pond culture of this highly favoured fish species was seriously impeded by Thaparocleidus (Ancylodiscoides) vistulensis infection causing fatal damage to the gills. The specific feature of this disease was that out of the three Thaparocleidus species [T. magnus (Bychowsky et Nagibina), T. siluri (Zandt) and T. vistulensis (Siwak)] common in natural waters, only $T$. vistulensis had adapted to pond culture and had become a serious pathogen. In Japan, Ogawa and Egusa (1976) described a heavy Pseudodactylogyrus infection caused by Pseudodactylogyrus anguillae (Yin et Proston) and Pseudodactylogyrus bini (Kikuchi) in cultured Japanese eel (Anguilla japonica Temminck et Schlegel) stocks. At the time when intensive culture of the European eel (Anguilla anguilla L.) was started in Hungary, Székely and Molnár (1987) observed pseudodactylogyrosis in this eel species. Pseudodactylogyrosis became a permanent problem in Danish recirculation systems (Buchmann, 
$1988 a, b$ ), and histopathological studies of this infection showed a similar picture to that found in Dactylogyrus and Thaparocleidus infections (Buchmann, 2012). Therefore, it is no surprise that in the intensive cage culture of barramundi (Lates calcarifer Bloch) the first pathogen hampering the propagation of this fish was precisely a monogenean species, Neobenedenia melleni (MacCallum, 1927) (Deveney et al., 2001). Due to the rapid development of marine cage culture systems and the intensive culture of some freshwater species, a whole series of infections caused by different monogenean species has been reported recently (GonzalezLanza et al., 1991; Roubal, 1995; Dezfuli et al., 2007; Sitja-Bobadilla and Alvarez-Pellitero, 2009; Merella et al., 2009; Del Rio-Zaragoza et al., 2010; Yardimci and Pekmezci, 2012; Jerônimo et al., 2014).

This paper reports the histological changes caused by A. paradoxus during a massive infection associated with mortality in an intensively cultured pikeperch stock.

\section{Materials and methods}

In an open-air concrete basin of $150 \mathrm{~m}^{3}$ volume, supplied with parasite-free well water, one-year-old pikeperch of 90 to $110 \mathrm{~g}$ weight were cultured. In the spring of 2015, an intensive infection with the monogenean Ancyrocephalus paradoxus was unexpectedly recorded. The gills of the fish were infected by 50 to 800 specimens (Fig. 1). The infected fish stopped feeding, their gills showed a pale colour, and about $10 \%$ of the heavily infected specimens died of the infection. Gill samples of three fish fixed in $10 \%$ buffered formalin were sent to the laboratory for histological examination. The gills of these fish specimens were infected by 360 to 420 worms. The larger, more heavily infected lateral hemibranchia close to the gill covers were selected for histology. Tissue samples were embedded in paraffin wax, cut to $4-5 \mu \mathrm{m}$ thick sections, and stained with haematoxylin and eosin (HE). A long-shot picture of parasites adhering to a hemibranchium was taken with an Olympus C4040 camera attached to an Olympus SZX9 stereomicroscope, while histological sections were photographed with an Olympus DP 20 digital camera attached to an Olympus BH2 microscope.

\section{Results}

Gill hemibranchia of pikeperch submitted for histological examination showed a medium-severity infection with 50 to 60 worms (Fig. 1). The haptoral disc with hooks and anchors and a small part of the bodies of these relatively large (up to $4.5 \mathrm{~mm}$ ) monogeneans were located in the gill tissue or between filaments (in the inter-filamental part), while the larger part of their body protruded from the filaments. At the sites where worms attached to the gill filaments 
a deep depression was formed, the gill lamellae were replaced by proliferating epithelial cells, at the periphery of which the remnants of damaged lamellae were still visible (Fig. 2). Proliferation of the epithelium in the gills was observed around the short inter-filamental portion of the worms as well (Fig. 3). Due to intensive proliferation of the damaged epithelium, presumably induced by the feeding mechanism of the worms, the ends of the heavily infected gill filaments fused, and formed clubbed structures in which only the remnants of the former lamellae could be observed (Fig. 4). The granulation tissue of the clubbed filaments was mostly built up of proliferating epithelial (epitheloid) cells, on the surface of which an increased number of goblet cells was recorded. However, even in these heavily infected hemibranchia there were areas containing uninfected filaments with undamaged lamellae (Fig. 5). In heavily infected parts of the hemibranchia, the worms were seen attached to the gills mostly at the basal parts of the gill filaments. In that region, dozens of cross-sectioned worms were seen among the filaments lacking lamellae (Fig. 6). At sites where the worms fixed to the filaments the haptor of the worm with anchors and hooks intruded deep into the filament tissue (Fig. 7) and the short stout anchors of $A$. paradoxus piercing into the connective tissue of the gill rays could also be seen (Fig. 8). No mononuclear cells were recorded in that region but the damaged epithelium was infiltrated by red blood cells released from injured capillaries.

\section{Discussion}

When starting to culture a fish species, first of all after the intensification of technology, many diseases including parasitic infections might appear. Among the parasites, the species having a direct developmental cycle, such as monogeneans, are usually the first pathogens to emerge in fish farming. Heavy infections develop whenever a new fish species is selected for pond culture. To avoid unexpected infections, efforts are made to culture these fish in parasite-free water and to feed them with pathogen-free food; in addition, precautions are taken to avoid the accidental introduction of pathogens with instruments. Although in the case reported here all of these measures had apparently been taken, an outbreak of ancyrocephalosis occurred, the origin of which remained unknown.

Since Dactylogyrus vastator invasion in carp was first described by Wunder (1929), several reports have been published on similar infections of cultured fish species. First of all the pathology of D. vastator infection was studied further (Paperna, 1964; Kollmann, 1972), but papers were published on diseases caused by other carp parasites, such as D. extensus and D. anchoratus and Dactylogyrus spp. of the Chinese major carps (Bauer and Nikolskaya, 1954; Prost, 1963; Bauer et al., 1969). Paperna (1964) described that in extremely heavy infestation with $D$. vastator 


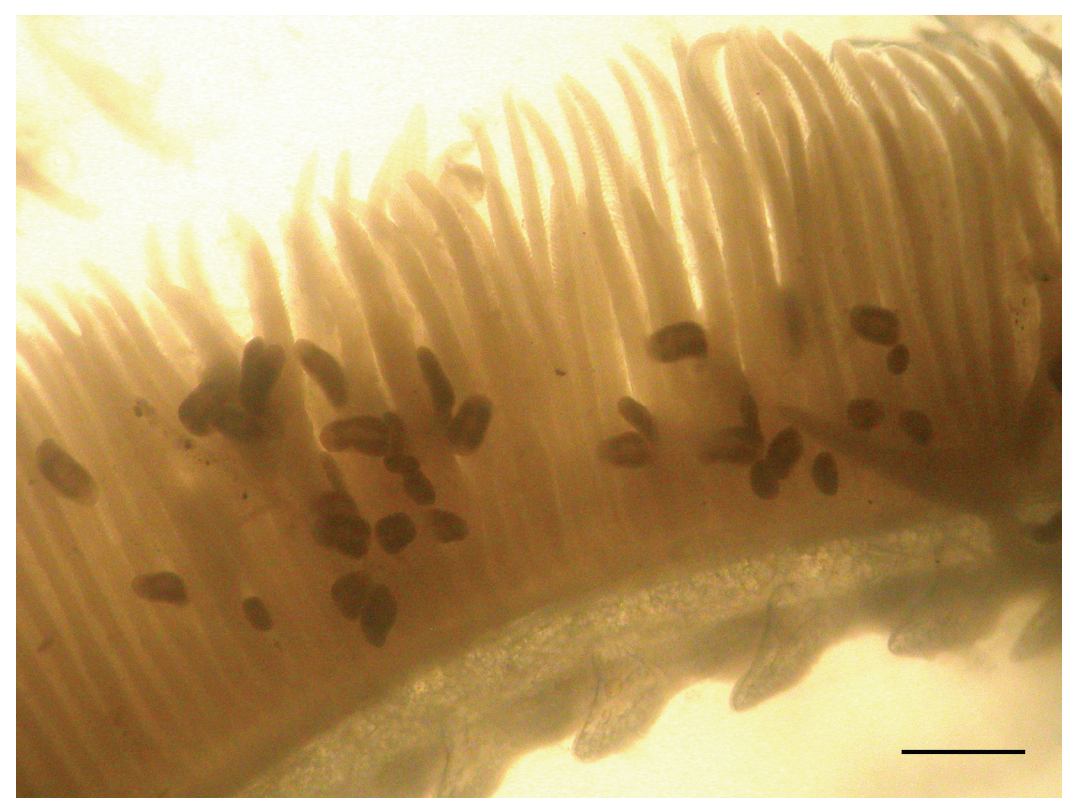

Fig. 1. Part of a pikeperch hemibranchium infected by Ancyrocephalus paradoxus specimens. Bar $=1.5 \mathrm{~mm}$

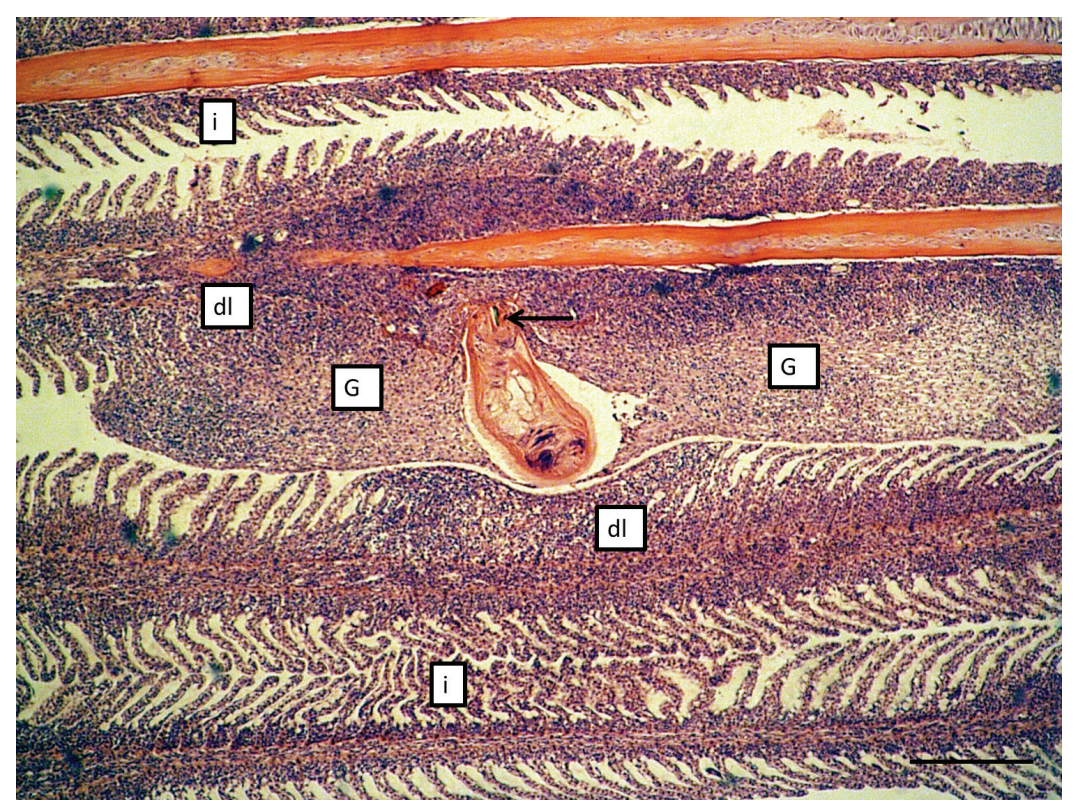

Fig. 2. Caudal end of an Ancyrocephalus paradoxus specimen (arrow) piercing its anchors into the gill filament. The worm is surrounded by granulation tissue $(\mathrm{G})$. The remnants of the damaged lamellae (dl) are pushed deep into the granulation tissue. On the uninfected filaments intact lamellae (i) are located. Histological section, haematoxylin and eosin (HE) staining; bar $=200$ micrometres 


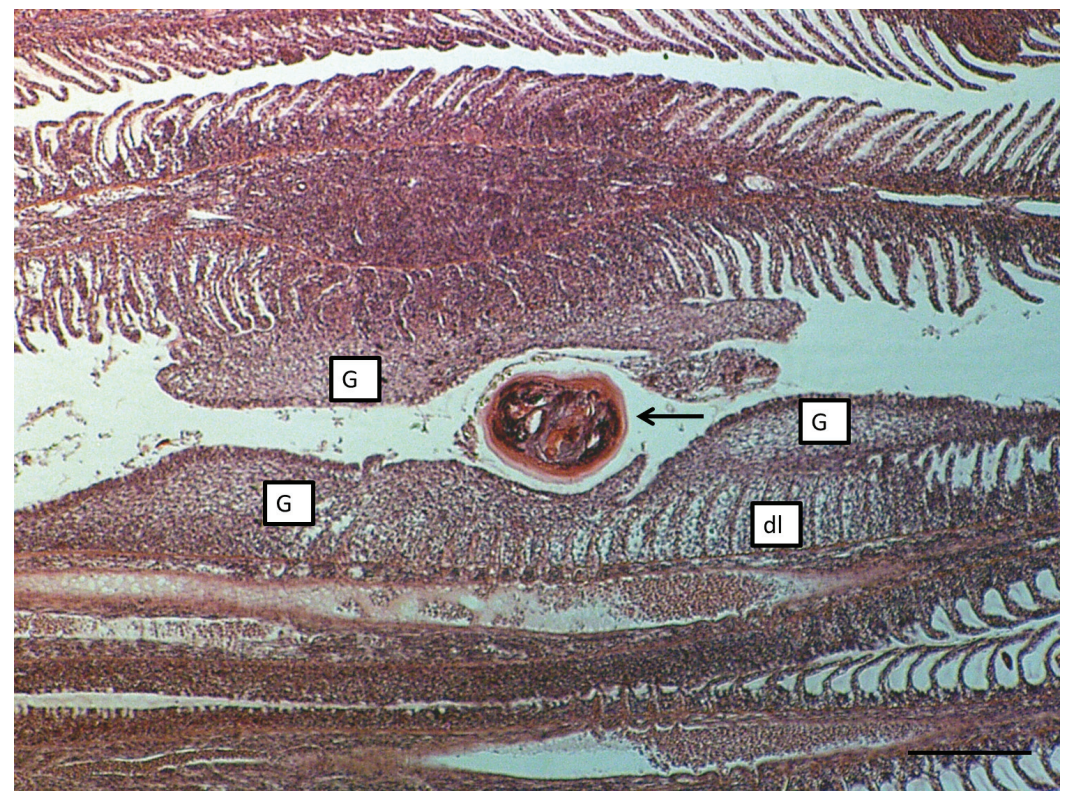

Fig. 3. Cross-section of the inter-filamental segment of an Ancyrocephalus paradoxus specimen (arrow) inducing granulation tissue $(\mathrm{G})$ formation in the neighbouring filament tissues. $\mathrm{dl}=$ damaged lamellae. Histological section, HE staining; bar $=200$ micrometres

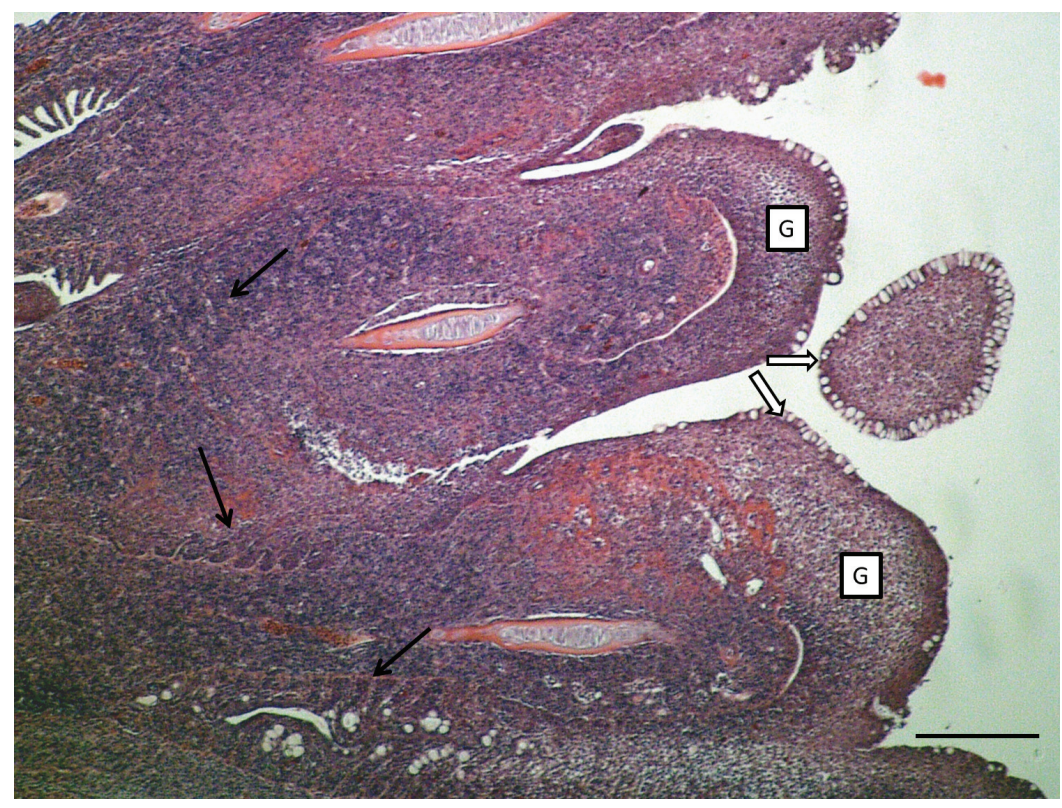

Fig. 4. Clubbing and fusion of the ends of heavily infected filaments. Some damaged lamellae (arrows) are still seen in the granulation tissue (G). An increase in the number goblet cells (open arrow) is also common. Histological section, HE staining; bar $=200$ micrometres 


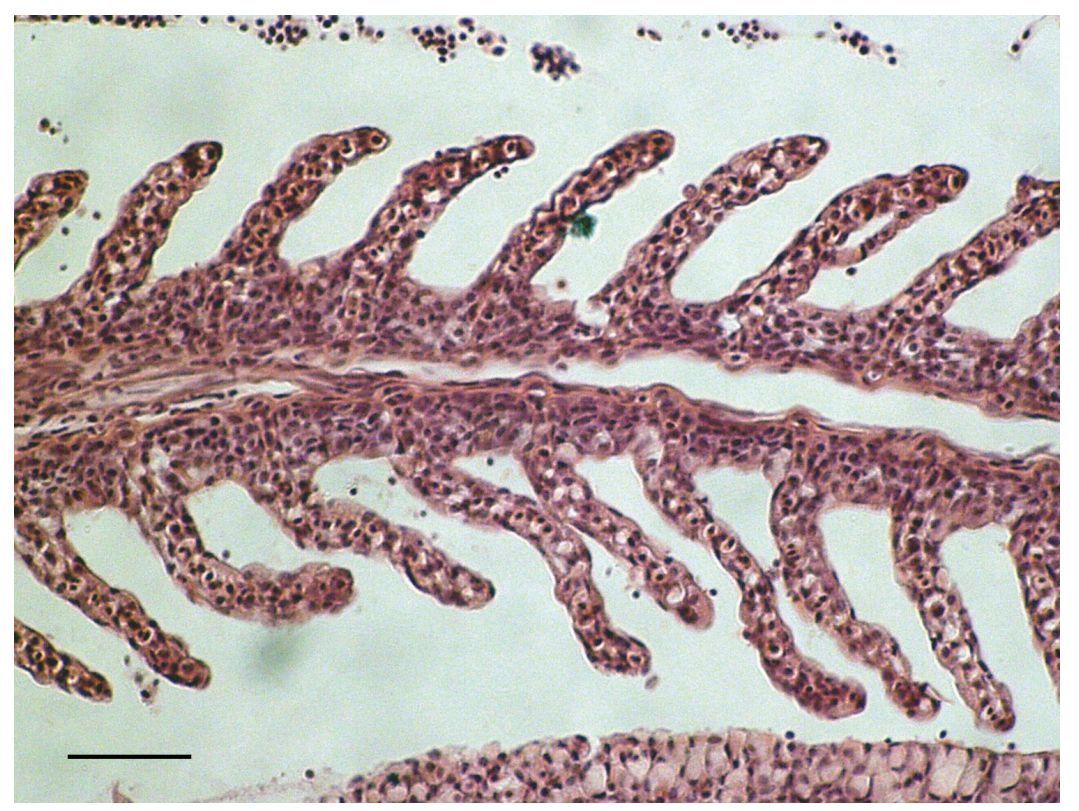

Fig. 5. Uninfected regions of the filaments with undamaged lamellae. Histological section, HE staining; bar $=40$ micrometres

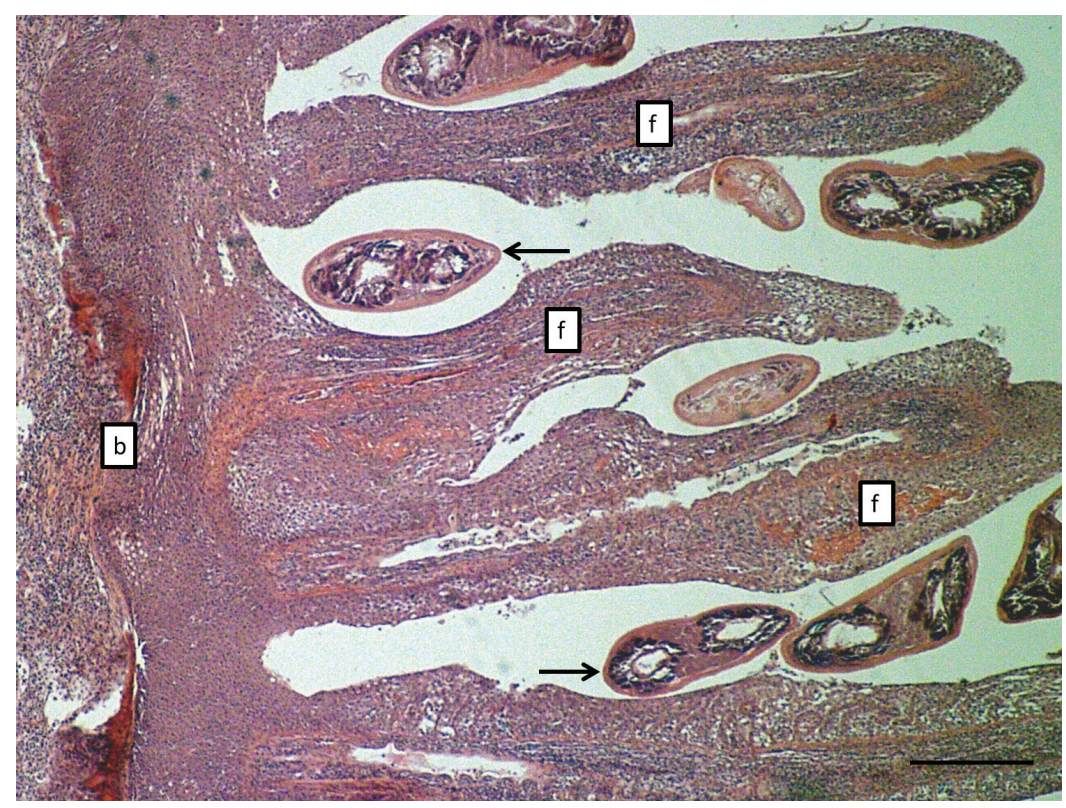

Fig. 6. Cross-sectioned worms (arrows) among filaments (f) denuded of lamellae, close to the base of the filaments (b). Histological section, HE staining; bar $=200$ micrometres 


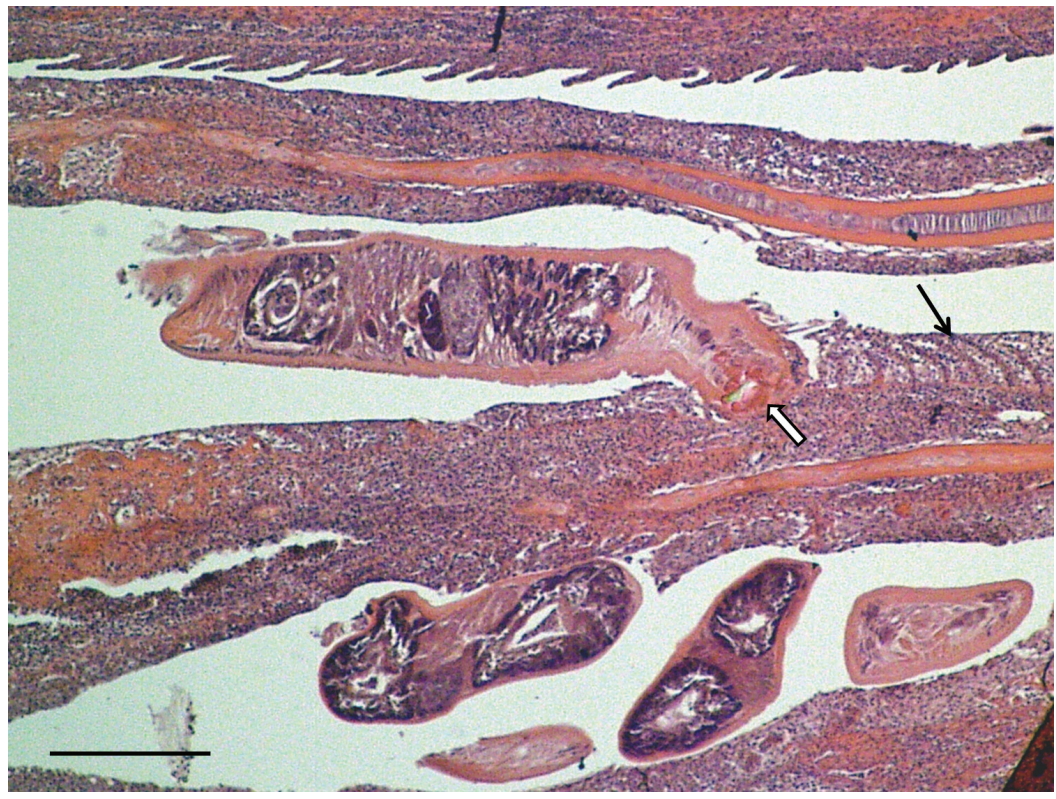

Fig. 7. An Ancyrocephalus paradoxus worm fixed to the gill filament, forming a depression (open arrow). Only the remnants of lamellae are seen in these filaments (arrows). Histological section, HE staining; bar $=200$ micrometres

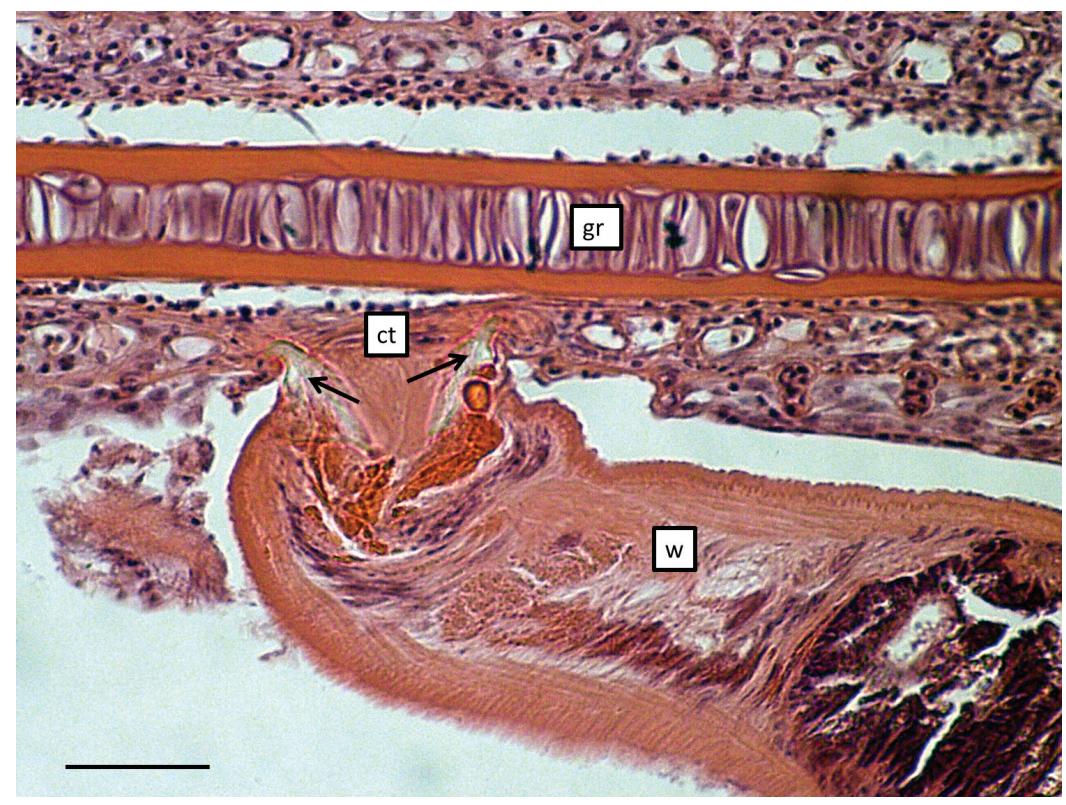

Fig. 8. An Ancyrocephalus paradoxus worm (w) piercing its anchors (arrows) deep into the connective tissue (ct) of the cartilaginous gill ray (gr). Histological section, HE staining; $\mathrm{bar}=50$ micrometres 
carp fry died of damage of the respiratory epithelium before the lesions characteristic of dactylogyrosis could have appeared. A similar phenomenon was found in D. lamellatus infection of the grasscarp, when highly intensive infection resulted in desquamation of the lamellar epithelium and death of the affected fish (Molnár, 1972). Paperna (1964) and Molnár (1972) agreed that in less acute cases a host response with hyperplasia of the epithelial cells accompanied by massive proliferation of goblet cells took place, the gills were covered by an abundant amount of thick mucus only partially originating from the increased number of goblet cells but mainly from the cytoplasm of disrupted cells and the destroyed vascular network. Due to intensive proliferation of the interlamellar epithelium, the lamellae were overgrown by the proliferating epithelial cells, and the remnants of damaged capillaries were seen deep inside this regeneration tissue. The neighbouring filaments fused and formed projections denuded of lamellae, a process generally known as clubbing. Although this host reaction eliminated most of the parasites, many fish died of suffocation. A similar pattern of infection was found in cultured sheatfish fingerlings with Thaparocleidus (Ancylodiscoides) infection. This latter differed, however, from Dactylogyrus infection in that most of the worms survived and could be found on and within the clubbed filaments. When studying infection of the European eel with Pseudodactylogyrus anguillae and P. bini, Buchmann (2012) found similar pathological host responses. He found hyperplasia of mucous cells and gill epithelial cells with excess production of mucus and fusion of the gill lamellae and primary filaments, which led to clubbing and fusion of the neighbouring filaments. Specialists studying the infection of freshwater fishes with monopisthocotylean monogeneans (Paperna, 1964; Molnár, 1972, 1980; Buchmann, 2012) agreed that these severe degenerative and proliferative changes were mostly restricted to the gill epithelium. However, authors studying blood-feeding polyopisthocotylean monogeneans in marine fishes reported more complex host reactions. Ogawa (2012) described that Heterobothrium hirame Ogawa infection of the olive flounder resulted in the development of severe anaemia and, in addition to inflammation, hyperplasia, necrosis in the buccal cavity wall and a dense granular cell infiltrate with monocytes and granulocytes were observed. Other authors (Gonzalez-Lanza et al., 1991; Roubal, 1995; Dezfuli et al., 2007; Sitja-Bobadilla and AlvarezPellitero, 2009; Merella et al., 2009; Yardimci and Pekmezci, 2012) reporting on infections of marine fishes found only local changes at the attachment sites of the worms with haemorrhages, mucoid exudates, erosion of the lamellar epithelium, and local hyperplasia on the filaments. Clubbing of filaments was not observed but all of the above authors reported fusion of the secondary lamellae besides degenerative changes at the attachment points of monogeneans. Although in the above cases severe damage of the gills was reported, these infections can be assigned to the category of local damage rather than disease. In a similar way, infections of the marine fish Lutjanus guttatus with Haliotrema spp. and of the 
freshwater fish Piaractus mesopotamicus with the monopisthocotylid Anacanthorus penilabiatus (Del Rio-Zaragoza et al., 2010; Jerônimo et al., 2014) are regarded as conditions causing partial damage to the gill filaments, despite the fact that the above authors also found marked haematological changes with elevated percentages of thrombocytes, granulocytes, neutrophils, and eosinophils.

In general, the histological picture of Ancyrocephalus infection of the pikeperch showed a pattern very similar to that of Thaparocleidus infection of the sheatfish and Pseudodactylogyrus infection of the eel. In all cases, the anchors of the worms were located in deep impressions inside the filaments. The lamellae were damaged and overgrown by proliferation tissue in areas where the worms attached to the filaments. In more heavily infected filaments no lamellae were found anymore and the ends of the filaments fused ('clubbing'), which is also characteristic of Dactylogyrus and Thaparocleidus infections. The changes found in Ancyrocephalus infection corresponded to those seen in monogenean infections of freshwater fishes and differed from such infections of marine species in which only local changes have been found until now. These preliminary data do not allow us to draw conclusions on the pathogenicity of this parasite; however, the mortalities found and the severe gill damage caused by the parasite indicate that ancyrocephalosis might become a permanent threat in the prospective culture of this fish species in intensive systems.

\section{Acknowledgements}

This study was supported by the Hungarian Scientific Research Fund (OTKA, project no. K 100132). The authors thank Ms. Györgyi Pataki for preparing the histological slides.

\section{References}

Bauer, O. N. and Nikolskaya, N. P. (1954): Dactylogyrus solidus Achmerov, its biology, development and its importance in fish culture [in Russian]. Zool. Inst. AN SSSR 4, 99-109.

Bauer, O. N., Musselius, V. A. and Strelkov, Ju. A. (1969): Diseases of Pond Fishes [in Russian]. Publ. House Kolos, Moscow. 335 pp.

Behrmann-Godel, J., Roch, S. and Brinker, A. (2014): Gill worm Ancyrocephalus percae (Ergens 1966) outbreak negatively impacts the Eurasian perch Perca fluviatilis L. stock of Lake Constance, Germany. J. Fish Dis. 37, 925-930.

Buchmann, K. (1988a): Feeding of Pseudodactylogyrus bini (Monogenea) from Anguilla anguilla. Bull. Eur. Ass. Fish Pathol. 8, 79-81.

Buchmann, K. (1988b): Interactions between the gill-parasitic monogeneans Pseudodactylogyrus anguillae and P. bini and the fish host Anguilla anguilla. Bull. Eur. Ass. Fish Pathol. 8, 98-99.

Buchmann, K. (2012): Pseudodactylogyrus anguillae and Pseudodactylogyrus bini. In: Woo, P. T. K. and Buchmann, K. (eds) Fish Parasites: Pathobiology and Protection. CAB International, Wallingford, UK. pp. 209-224. 
Del Rio-Zaragoza, O. B., Fajer-Avila, E. J. and Almazan-Rueda, P. (2010): Haematological and gill responses to an experimental infection of dactylogyrid monogeneans on the spotted rose snapper Lutjanus guttatus (Steindachner, 1869). Aquacult. Res. 41, 1592-1601.

Deveney, M. R., Chisholm, L. A. and Whittington, I. D. (2001): First published record of the pathogenic monogenean parasite Neobenedenia melleni (Capsalidae) from Australia. Dis. Aquat. Org. 46, 79-82.

Dezfuli, B. S., Giari, L., Simoni, E., Menegatti, R., Shinn, A. P. and Manera, M. (2007): Gill histopathology of cultured European sea bass, Dicentrarchus labrax (L.), infected with Diplectanum aequans (Wagener 1857) Diesing 1958 (Diplectanidae: Monogenea). Parasitol. Res. 100, 707-713.

Ergens, R. (1966): Revision of the helminthofauna of fishes in Czechoslovakia III. Genus Ancyrocephalus (s.1.) Creplin, 1839 (Monogenoidea: Dactylogyridae). Folia Parasitol. 13, 28-35.

Gonzalez-Lanza, C., Alvarez-Pellitero, P. and Sitja-Bobadilla, A. (1991): Diplectanidae (Monogenea) infestations of sea bass, Dicentrarchus labrax (L.) from the Spanish Mediterranean area. Histopathology and population dynamics under culture conditions. Parasitol. Res. 77, $307-314$.

Gussev, A. V. (1985): Monogenea. In: Bauer, O. N. (ed.) Key to the Determination of Parasites of Freshwater Fishes of the USSR. Vol. 2. [in Russian]. Nauka, Leningrad. pp. 10-425.

Jerônimo, G. T., Pádua, S. B., Bampi, D., Gonçalves, E. L. T., Garcia, P., Ishikawa, M. M. and Martins, M. L. (2014): Haematological and histopathological analysis in South American fish (Piaractus mesopotamicus) parasitized by monogenean (Dactylogyridae). Braz. J. Biol. 74, 1000-1006.

Kollmann, A. (1972): Dactylogyrus vastator Nybelin, 1924 (Trematoda, Monogenoidea) als Krankheitserreger auf den Kiemen des Karpfens (Cyprinus carpio L.). 3. Teil. Z. Wiss. Zool. (Leipzig) 185, 1-54.

Merella, P., Cherchi, S., Garippa, G., Fioravanti, M. L., Gustinelli, A. and Salati, F. (2009): Outbreak of Sciaenacotyle panceri (Monogenea) on cage-reared meagre Argyrosomus regius (Osteichthyes) from the western Mediterranean Sea. Dis. Aquat. Org. 86, 169-173.

Molnár, K. (1962): Fish parasites from Lake Balaton and pond farms [in Hungarian]. Ann. Biol. Tihany 29, 117-127.

Molnár, K. (1968a): Die Wurmkrankheit (Ancylodiscoidose) des Welses (Silurus glanis). Z. Fischerei NFBd 16, 31-41.

Molnár, K. (1968b): Beiträge zur Kenntnis der Fischparasiten in Ungarn. 3. Weitere Monogeneidenarten aus Fischen. Acta Vet. Acad. Sci. Hung. 18, 295-311.

Molnár, K. (1971): Studies on gill parasitosis of the grasscarp (Ctenopharyngodon idella) caused by Dactylogyrus lamellatus Achmerov, 1952. I. Morphology and biology of Dactylogyrus lamellatus. Acta Vet. Acad. Sci. Hung. 21, 267-289.

Molnár, K. (1972): Studies on gill parasitosis of the grasscarp (Ctenopharyngodon idella) caused by Dactylogyrus lamellatus Achmerov, 1952. IV. Histopathological changes. Acta Vet. Acad. Sci. Hung. 22, 9-24.

Molnár, K. (1980): A histological study on ancylodiscoidosis in the sheatfish (Silurus glanis). Helmintologia 17, 117-126.

Molnár, K. and Székely, Cs. (1995): Parasitological survey of some important fish species of Lake Balaton. Parasitol. Hung. 28, 63-82.

Ogawa, K. (2012): Heterobothrium okamotoi and Neoheterobothrium hiramae. In: Woo, P. T. K. and Buchmann, K. (eds) Fish Parasites: Pathobiology and Protection. CAB International, Wallingford, UK. pp. 245-259.

Ogawa, K. and Egusa, S. (1976): Studies on eel pseudodactylogyrosis - I. Morphology and classification of three eel dactylogyrids with a proposal of a new species, Pseudodactylogyrus microrchis. Bull. Jpn. Soc. Sci. Fish 42, 395-404.

Paperna, I. (1964): Host reaction to infestation of carp with Dactylogyrus vastator Nybelin, 1924 (Monogenea). Bamidgeh 16, 129-141. 
Peterka, J., Matena, J. and Lipka, J. (2003): The diet and growth of larval and juvenile pikeperch [Stizostedion lucioperca (L.)]: A comparative study of fishponds and a reservoir. Aquaculture Intern. 11, 337-348.

Prost, M. (1963): Investigations on the development and pathogenicity of Dactylogyrus anchoratus (Duj., 1845) and D. extensus Mueller et v. Cleave, 1932 for breeding carps. Acta Parasitol. Polon. 11, 17-47.

Roubal, F. R. (1995): Microhabitats, attachment of eggs and histopathology by the monogenean $\mathrm{Al}$ lomurraytrema robustum on Acanthopagrus australis (Pisces: Sparidae). Int. J. Parasitol. 3, 293-298.

Sitja-Bobadilla, A. and Alvarez-Pellitero, P. (2009): Experimental transmission of Sparicotyle chrysophrii (Monogenea: Polyopisthocotylea) to gilthead seabream (Sparus aurata) and histopathology of infection. Folia Parasitol. 56, 143-152.

Starovoytkov, V. K. (1989): The distribution of Ancyrocephalus paradoxus (Monogenea, Ancyrocephalidae) on gills of Stizostedion lucioperca [in Russian]. Parasitologiya 23, 40-47.

Székely, Cs. and Molnár, K. (1987): Mebendazole is an efficacious drug against pseudodactylogyrosis in the European eel (Anguilla anguilla). J. Appl. Ichthyol. 3, 183-186.

Wilde, J. (1937): Dactylogyrus macracanthus Wegener als Krankheitserreger auf dem Kiemen der Schleie (Tinca tinca L.). Z. Parasitenk. 9, 203-236.

Wunder, W. (1929): Die Dactylogyruskrankheit der Karpfenbrut ihre Ursache und ihre Bekämpfung. Z. Fischerei 27, 511-545.

Yardimci, B. and Pekmezci, G. Z. (2012): Gill histopathology in cultured sea bass (Dicentrarchus labrax (L.) coinfected by Diplectanum aequans (Wagener, 1857) and Lernanthropus kroyeri (van Beneden, 1851). Ankara Üniv. Vet. Fak. Derg. 59, 61-64.

Zakęś, Z., Hopko, M., Kowalska, A., Partyka, K. and Stawecki, K. (2013): Impact of feeding pikeperch Sander lucioperca (L.) feeds of different particle size on the results of the initial ongrowing phase in recirculation systems. Arch. Pol. Fish 21, 3-9.

Zakęś, Z., Kowalska, A., Czerniak, S. and Demska-Zakęś, K. (2006): Effect of feeding frequency on growth and size variation in juvenile pikeperch, Sander lucioperca (L.). Czech J. Anim. Sci. 51, 85-91. 